\title{
How Oil Autocracies Learn to Stop Worrying: Central Eurasia in 2008 Global Financial Crisis
}

\author{
Anar Ahmadov \\ Post-Soviet Affairs \\ (forthcoming)
}

\begin{abstract}
Autocracies in developing countries are more likely to collapse during economic crises. Some influential works and popular media extend this argument to oil-rich autocracies, but crossnational empirical studies find little evidence to support this view. Yet, while the causes of their stability during boom periods are well understood, how oil-rich autocratic regimes remain stable during busts is underexplored. This article advances an explanation that refines and complements existing accounts. I argue that we need to take into account three interrelated factors that currently are likely to stabilize oil-rich autocracies: considerable savings, policy learning, and sustenance of coercive capacity. Leveraging evidence drawn from 40 original interviews, documents, news media, and academic literature, I investigate the role of these factors through a comparative case study of Azerbaijan, Kazakhstan, and Turkmenistan during the 2008 global economic turmoil. The findings highlight the ruling elites' ability to amass sizeable savings that later provide safety cushions, to update their know-how through drawing lessons within and beyond fiscal policy, and to sustain coercive capacity without resorting to overt repression. Through economic crises, they may learn to not escape the "resource curse," but to escape despite the "resource curse."
\end{abstract}




\section{How Oil Autocracies Learn to Stop Worrying: Central Eurasia in 2008 Global Financial Crisis}

"Kogda zakonchitsya neft', nash prezident umret." ("When the oil runs dry, our president will die.") From a satirical song by DDT, a popular Russian rock band

\section{INTRODUCTION}

This article explores sources of regime stability in oil-rich ${ }^{1}$ autocracies during external economic crises by using a comparative case study of Azerbaijan, Kazakhstan, and Turkmenistan during 2008 global financial crisis (GFC). Conventional views argue that autocracies are likely to experience regime instability, breakdown or liberalization under the pressure from external economic shocks. Influential studies expect oil-rich autocracies to be particularly susceptible to such crises given the highly volatile nature of their main resources. From this perspective, Central Eurasia's oil-rich autocracies should have experienced serious instability in the aftermath of the GFC, akin to that confronted by comparable regimes in the Middle East and North Africa, such as Algeria, Bahrain, and Libya, which prior to the crisis exhibited many of the same economic, institutional, and cultural characteristics, such as cross-nationally similar petroleum rents, resource dependencies, autocratic governance, colonial past, and Islamic cultural legacy. Yet, they endured it unharmed. Furthermore, while these regimes had similar initial conditions but over time embarked on different trajectories that should have entailed varying levels of vulnerability, it is puzzling why, despite these differences, all three emerged from the crisis similarly intact.

A serious reinvestigation into the sources of regime stability in oil-rich autocracies has critical academic and policy relevance. Around 35 out of 50 petroleum-rich countries have had non-democratic, mostly autocratic regimes, and many have suffered from other manifestations of the "resource curse", such as resource dependence, poor economic growth, and corruption. ${ }^{2}$ Given their resources, these regimes represent some of the most robust authoritarian political systems. Some, like Russia, Venezuela and Saudi Arabia, are believed to be proactive in autocratic diffusion (Cameron and Orenstein 2012; Vanderhill 2012; Weyland 2017). Out of 79 Sovereign Wealth Funds (SWF), increasingly influential state-owned funds with large investment operations globally, 32 belong to oil-rich autocracies. These funds have total assets of \$3.4 trillion: $45 \%$ of total SWF assets globally (SWFI 2017). The ongoing wars in Iraq, Libya, and Syria and Vladimir Putin's assertive foreign policy have drawn attention to manifold domestic and international ramifications of autocratic (in)stability in oil-rich polities. Popular media offers hope that financial crises shake political systems in oil-rich autocracies and provide "windows of opportunity" to liberalize them (Friedman 2006). Yet, short of foreign intervention, these regimes persist despite fiscal shocks. This tenacity constitutes a major question.

Existing literature on regime stability in oil-rich autocracies offers many insights but has several limitations. First, while the causes of their stability during boom periods are well understood, how oil-rich autocracies remain stable during busts is underexplored. Second, much of our thinking on this topic draws on the experience of oil-rich autocracies during the international economic crises of the 1970s and 1980s. For example, Karl (1997) focuses on Venezuela, Nigeria, Algeria, Iran, and Indonesia (189-221), Beblawi and Luciani (1987) on the Middle East, and Smith (2007) on Iran and Indonesia, all between 1960-1980. But should we expect that the factors explaining autocratic resilience in previous crises retain explanatory power over time, despite what we now know about autocratic adaptability? Furthermore, the Middle East and North Africa and major states, like Russia, have received disproportionate attention. Yet, developments in other, currently less visible oil-rich autocracies can both cast light on important explanatory factors and have drastic social consequences. Finally, many 
studies rely disproportionately on aggregate indicators and secondary evidence, and contain little evidence drawn from actors involved in the processes.

This article aims to help rectify these shortcomings. Its distinct contribution is in updating our knowledge on oil-fuelled autocratic resilience against the backdrop of the 2008 GFC, proposing three factors that refine and complement existing explanations, offering a comparative study of the cases of three oil-rich autocracies in Central Eurasia, and leveraging evidence from around 40 original interviews. Substantively, I argue that a configuration of three interrelated factors should be taken into account. First, unlike their predecessors, oil-rich autocracies facing the GFC were more likely to have amassed considerable savings that would provide safety cushions for years of distress. Second, they were likely to benefit from policy learning and not only in fiscal policy, but also in political measures, monetary policy, and coercive strategies. Their updated know-how would result in contextualized policy adjustment, which in turn would prop their regime's stability. Third, I propose to re-conceptualize the role of coercion, in particular by focusing on coercive capacity rather than overt repression during the crises.

\section{Why Do OIL-Rich Autocracies ENDURE CRISES? Key EXPLANATIONS}

One of the stylized facts of political regime studies is that autocracies in developing countries are more likely to collapse during economic crises (Gasiorowski 1995; Haggard and Kaufman 1995; Linz and Stepan 2011). Key explanatory variables include the crisis of legitimacy among high echelons of power (Linz and Stepan 2011), lower capacity to repress and manipulate political institutions (Haggard and Kaufman 1995), and varying mobility of the elite members' capital assets, which can result in disordered adjustment policy (Pepinsky 2009). Some influential studies and popular media extend this argument to oil-rich autocracies (Karl 1999; Luciani 1994; Friedman 2006). When they receive considerable amounts of external rents, governments in oil-rich autocracies use these windfall revenues to fuel their patronage networks, buy off the population through high public spending, and maintain robust security apparatuses to repress dissent (Anderson 1987; Beblawi and Luciani 1987; Karl 1997; Ross 2001). As a result, the autocratic rule remains robust.

Yet, it is the bust period that brings critical challenges. A slump in oil revenues is believed to cause critical seizures in domestic rent distribution, entailing splits within the ruling elites and opening space for anti-regime challenges that have been kept dormant during the boom, thus increasing the likelihood of regime breakdown (Karl 1999; Luciani 1994).

However, cross-national empirical studies find little evidence to support this hypothesis. Although during fiscal crises of 1970s-1980s their patronage rents shrank significantly, relatively few oil-rich autocracies broke down. Furthermore, they appear more stable in the face of such crises than other nondemocratic regimes (Smith 2004). Furthermore, in mineral resourcereliant developing countries economic volatility can coexist with political stability for long periods (Dunning 2005). Therefore, the vulnerability argument may be based on a small sample of regimes that indeed collapsed because of external economic shocks. Yet, there is limited understanding of mechanisms that keep oil-rich autocratic leaders in power during such crises. Four variables, reviewed below, are believed to prevent or repress elite splits and anti-regime popular mobilization, thus leading to autocratic stability.

\section{Weak Social Organization}

Rentier state theory argues that large external revenues from natural resources, particularly petroleum, allow leaders in producing countries to use these funds to sponsor classes and groups loyal to the regime while weakening autonomous social organizations (Beblawi and Luciani 1987; Karl 1997; Ross 2001). The autocratic rule in oil-rich countries is thus made durable by weak social organization. Due to this effect, it is argued, during the times of economic crises the leaders face weakly organized societies. The key issue with this argument is that it might be 
attributing an autonomous role to a factor that is itself likely to be, to a large extent, a function of state strength and previous repression.

\section{Repression}

Second, the robustness of autocratic regimes across the Middle East is explained by the regional oil-rich rulers' ability to sustain impressive coercive apparatuses and repress dissent (Bellin 2004). Some cross-national statistical studies support this view (Ross 2001). Oil income can lower the risk of incumbent autocrats being ousted by rival autocratic groups and increase military spending, which may subsequently deter coups (Wright, Frantz, and Geddes 2013). However, this argument does not distinguish between booms when oil-rich autocracies are benefiting from their wealth and busts when their fiscal capacities may be jeopardized.

If we introduce this distinction, we face two issues that cast doubt on the role of repression. The first question is whether their repressive abilities remain strong during busts. Such abilities are linked to fiscal health (Bellin 2004). Therefore, when fiscal health is compromised during an economic crisis, as many scholars believe, we should expect weakened coercive capabilities and higher likelihood of regime instability. The second issue is whether oil-rich autocracies indeed repress more and whether it works. While of the 21 cases surveyed in one study, 15 regimes that were able to remain stable during the economic crises were also repressive, three regimes - in Congo, Ecuador, and Iran - fell despite their significant repression of dissent (Smith 2006). A cross-national statistical study finds that repression does not systematically explain why oil-rich autocracies remain stable in the face of economic crises (Smith 2004).

\section{International Support}

Third, given the strategic value of oil, foreign states may extend support to incumbent autocrats during booms and busts alike. They can also withhold pressure that would constrain the ruling elite's response to protest so as to avoid political instability that can undermine the security of oil supplies. As many oil-rich autocracies are in countries with majority Muslim populations, an added incentive for Western powers to prop the incumbents is to keep oil supplies away from radical Islamist groups (Bellin 2004). Foreign counterparts have extended their support during crises through economic aid, military assistance, or diplomatic intervention (Yom and Gause 2012). Autocratic stability can benefit from regional support by other countries, including through autocratic linkages (Brownlee 2017; Schmotz and Tansey 2018). Conversely, the fall of the Pahlavi regime in Iran is partly attributed to the withdrawal of support from its strongest ally, the United States (Snyder 1998). However, some dispute that U.S. support to the Pahlavi regime actually diminished (Kurzman 1996). In general, many studies of autocracy promotion fall short of demonstrating intentionality in advancing particular regime types abroad (Tansey 2016).

\section{Timing of Late Development}

Finally, the argument on the timing of late development holds that having strong societal opposition and low external rents at the outset of late development forces the ruling elites to build strong coalitions with important social groups. While such coalitions are later fueled by patronage rents coming from oil revenues, their strength does not depend on oil, thus making them robust in the face of economic crises. Moreover, in such cases "oil wealth can facilitate, rather than hinder, institutional development and coalition building" (Smith 2007, 48). Conversely, weak opposition and access to large rents at the outset is believed to result in shallow rent-based coalitions that are more vulnerable to economic crises.

This original account faces two limitations. First, it is unclear why the ruling elites would not renege on previous agreement with the incorporated social forces once the inflow of oil rents allows them to consolidate their power, particularly when oil industries are under state control after the 1960s wave of nationalizations (Ross 2012). Second, this argument is undermined by the critical differences between supposedly similar cases on which it rests. For one, petroleum 
rents (per capita) that Suharto's Indonesia received in 1960s and in 1970s was only 7 percent and 9 percent that of Pahlavi's Iran, respectively (author's calculation based on Ross and Mahdavi 2015). They also differed due to "the cross-nationally distinctive sociopolitical roots of the revolutionary movement" in Iran (Skocpol 1982, 268) and "a culture conducive to challenges to authority" such as Shi'a Islam that was historically intertwined with Iranian social life (ibid, 275).

\section{REVISITING THE SOURCES OF STABILITY}

I argue that the 2008 GFC demonstrates a need to take into account three other interrelated factors: considerable savings, policy learning, and sustenance of coercive capacity. These factors were likely to lead to contextualized policy adjustments - selective patronage, selective public spending, and sustained ability to repress. In turn, these adjustments would prevent ruling elite fractionalization and anti-elite popular mobilization, thus leading to regime stability. I discuss each factor below in more detail.

\section{Savings}

First, unlike their predecessors in previous decades, during the previous boom years preceding the GFC many oil-rich autocracies were likely to amass sizeable savings. These savings were then likely to provide safety cushions during the crisis. To untangle the link between regime outcomes and savings, we also need to consider different ways in which elites are likely to save for a rainy day. A stylized account that focuses on official budgets neglects reportedly vast financial streams that go unaccounted through corrupt mechanisms. While some savings can be accumulated in natural resource funds (NRFs), others are likely to flow into more impervious extra-budgetary bodies, including national energy companies and special presidential funds. These savings too can be used by ruling elites at the time when their collective survival is jeopardized.

\section{Policy Learning}

Building on the growing literature (Beissinger 2007; Chestnut 2010; Hall and Ambrosio 2017; Heydemann and Leenders 2011), I argue that policy learning should be factored in to explain the stability of oil-rich autocracies that face economic crises. Following Dolowitz and Marsh (2000, 5), I define policy transfer/learning as a "process in which knowledge about policies, administrative arrangements, institutions and ideas in one political setting (past or present) is used in the development of policies, administrative arrangements, institutions and ideas in another political setting."

The $21^{\text {st }}$ century oil autocracies are in a privileged position to learn. First, they are likely to have a major benefit of hindsight from the dramatic oil crises of the 1970 and 1980 . Second, while their structural constraints can promote rentier institutions during booms, they have more resources to draw on know-how that can help them to weather through financial turmoil. Finally, they are likely to encounter less tangible resistance to policies adopted through learning because they are more centralized and autonomous from societal forces than their resourcepoor peers - a condition that allows policy formation to incorporate learning instead of being driven by conflict (Hall 1993).

Oil-rich autocrats are likely to seek ideas, tools, and policy solutions on tackling the effects of externally-induced economic shocks that have been successful in similar environments and can be tailored to their political-economic contexts. Different contexts dictate what combination of policies is expedient for regime stability; for example, in what proportions should coercion, co-optation, and persuasion be adopted (Schatz 2009). Therefore, the rulers' prime sources of learning will not only be the experience of their reference groups who inhabit similar contexts - neighbors and similar states elsewhere, but also their own past experience and that of their predecessors (Beissinger 2007; Elkins and Simmons 2005; Gel'man and Lankina 2008; Hall and Ambrosio 2017). 
The rulers are likely to draw lessons eclectically, driven by their needs, through exchange of information with counterparts, information cascades (in which policymakers draw on accumulated insight from past decisions), reference group example, and epistemic community advice (Elkins and Simmons 2005; Vanderhill 2012). Finally, following the "chronological unfairness" hypothesis, while early victims' strategies are likely to be more spontaneous, later victims of exogenous shocks are likely to learn from their experience and be better organized (Anderson 2011; Beissinger 2007).

However, learning does not guarantee the success of the resulting policy and its role should not be overstated. Biases and limitations can curb actors' ability to achieve this (Elkins and Simmons 2005). Furthermore, as the case of former Ukrainian leader Viktor Yanukovich's import of strategies used by Middle Eastern autocrats in suppressing dissent in 2011 shows, autocratic rulers may adopt a strategy that has proven successful in a different setting but the context of their own polity may render this strategy ineffective or even counterproductive (Ambrosio 2017). Furthermore, not all policies might benefit from learning.

\section{Coercive Capacity}

Currently there is an ambiguity that conflates repression with coercive capacity, but these need not be the same: the former can be conceived to be resorted to when the latter fails to deter dissent. In other words, coercive capacity can act as a deterring mechanism that discourages collective action and precludes regime instability. Therefore, it may be premature to discard coercion as a factor based on the observation that some oil autocracies fall despite using overt repression during busts.

Second, by focusing on contemporaneous repression during crises, we might overlook path-dependent effects of past repression. The latter may not only marginalize regime challengers but also undermine the political, economic, and physical infrastructure that provides avenues for anti-regime interest aggregation, mobilization, and collective action. In Indonesia, Suharto's mass repression of a half-million group of Sukarno supporters and of Indonesian communists early on during his rule muted subsequent challenges to his power for decades. In Zaire, Mobutu Sese Seko's near demolition of non-resource sectors of the economy and destruction of the physical lines of communication subsequently limited challenges to his rule (Dunning 2005). Thus, past repression can enhance current coercive capacity.

Finally, contrary to assumptions that economic crises result in undermining the fiscal health of the coercive apparatus, its capacities need not be compromised. First, rulers are not likely to cut patronage across the board but to prioritize allocations. Second, the security establishment can be made part of patrimonial and kinship networks that tie different elements of the political elite together in durable non-financial links. Such linkages have been shown to be indispensable for regime unity when it faces significant challenges (Brownlee 2002).

\section{METHODOLOGY}

The cases of post-Soviet oil autocracies in Azerbaijan, Kazakhstan, and Turkmenistan are a fertile ground for examining these ideas. They share many similarities while differing in factors that are believed to entail differences in regime stability. Prior to independence in 1991, the three culturally close countries spent around 70 years under homogenizing Soviet rule, developed similar political patronage networks, had comparable economic systems, and were at similar levels of socioeconomic development (Luong and Weinthal 2010). By the onset of GFC, their political regimes looked alike (Overland, Kjaernet, and Kendal-Taylor 2010) and faced comparable international environment where they pursued pragmatic, "multi-vector" foreign policies that were neither fully pro-Western, nor pro-Russian. The countries had little conditionality pressure from international donors. Finally, prior to the crisis, they received large petroleum windfalls that were similar in international perspective (Ross and Mahdavi 2015). 
However, they differed in the strength of social organization, repression during the 2008 global economic crisis, and timing of late development. First, while Turkmenistan never had a tangible civil society or viable opposition, Azerbaijan and Kazakhstan had small, but functioning civil societies and organized political opposition (Ahmadov 2011; Guliyev 2013; La Porte 2015; Schatz and Maltseva 2012). Second, they differed in the level of repression during GFC, with Azerbaijan's government being more repressive than its counterparts (Cingranelli, Richards, and Clay 2014). Finally, they differed considerably in the timing of late development: the societal opposition to elites in the beginning of its independent development was considerably higher and external rents lower in Azerbaijan and Kazakhstan than in Turkmenistan (Luong and Weinthal 2010; Overland, Kjaernet, and Kendal-Taylor 2010). If the hypotheses on social organization, repression, and timing of late development are valid, the variation in these variables should entail differences in regime outcomes during the crisis.

The analysis draws on evidence from 40 original semi-structured interviews with regime actors and observers, reports from government and international development organizations, news media, and academic literature. Given the opacity of autocratic regimes, studies of authoritarian policy-making have understandable difficulties in investigating the relations between various factors. For example, it is difficult to demonstrate the role of learning and many studies resort to inferring it from correlations between policies in different settings (Hall and Ambrosio 2017). From this point of view, the evidence from author's interviews conducted during fieldwork between May 2009 and October 2010 in Azerbaijan, Kazakhstan, and Turkmenistan as well as Kyrgyzstan provides a distinct methodological leverage. ${ }^{3}$

Expanding on the framework by Ross (2001), I use this varied evidence base to shed light on potential links in each case between the hypothesized explanatory variables and regime outcomes through four channels: (1) monetary policy (e.g., exchange rate regulations, interest rates), (2) fiscal policy (e.g., tax base, tax exemptions, subsidies), (3) political measures (e.g., public office appointments, electoral changes, propaganda), and (4) repression (e.g., targeting strategies, repressive methods). I also draw on contemporaneous experiences of Kyrgyzstan and Tajikistan, the oil-rich autocracies' resource-poor but otherwise similar neighbors, to highlight similarities and differences.

\section{CENTRAL EURASia IN THE 2008 GlObal FinanCial CRisis}

Overall, the crisis led to a decline in oil prices as severe as the oil price drop in 1980s but steeper. It led to substantial economic recession in Azerbaijan, Kazakhstan, and Turkmenistan that is probably only partly reflected in official numbers (Figure 1) (EIU 2010a, 2010b, 2010c; Ibadoglu 2010; IMF 2011). Fiscal and export revenues fell sharply, and investment inflows and labor remittances dropped dramatically (EIU 2010a, 2010b, 2010c; IMF 2009; Milli Bank 2009). The banking sectors experienced substantial liquidity constraints (Ibadoglu 2010; IMF 2010c, 2011; EIU 2010c). Non-oil sectors contracted, and non-oil fiscal deficits increased. Problems in construction industries and non-oil manufacturing triggered increasingly large layoffs and unemployment as many enterprises were forced to put thousands of employees on unpaid leave (Ibadoglu 2010; EIU 2010b; IMF 2010c; EIU 2010c).

In Azerbaijan, the inability of several banks and state-owned enterprises to extend their foreign liabilities led to an abrupt drop in credit growth, significant contraction, and considerable unemployment (Ibadoglu 2010; IMF 2010). Similar issues, although less severely, hit Turkmenistan as its export revenues slumped and subsequently Russia shut down the route for the country's gas exports in 2009 (EIU 2010c; IMF 2010d; RFE/RL 2009c). Kazakhstan experienced a full-scale banking crisis. Several major and mid-size banks were on the verge of bankruptcy (Stempel 2010; IMF 2010c). By mid-2007, the crisis hit the real estate sector, leading to severe problems for construction companies, some of which went bankrupt, leading to increasing unemployment and serious protests from shareholders (Schatz and Maltseva 2012). 
Yet, despite the significant economic problems, the autocratic regimes retained their stability. Elite splits and popular mobilization were prevented. Judging from the overall lack of tangible challenges to the regimes, the publics remained compliant with the policies. By contrast, while the autocratic regime of Emomali Rahmon in Tajikistan also survived the crisis, the increasingly authoritarian regime of Kurmanbek Bakiyev in Kyrgyzstan fell in 2010 because of popular protest. What factors account for the stability of Central Eurasia's oil autocracies? To answer this question, I first detail regime responses to the crises.

[Figure 1 here]

\section{Azerbaijan}

Against the background of impending crisis, the government significantly lowered the reserve requirement on deposits from 12 to 0.5 percent, considerably reduced the refinancing rate from 15 to 2 percent, and restarted issuing subsidized mortgages (Milli Bank 2009). It made foreign exchange sales of more than $\$ 1$ billion to support the local currency (Manat) and large businesses (EIU 2010a). ${ }^{4}$ Another $\$ 1.1$ billion was provided in government-guaranteed credit to the stateowned International Bank of Azerbaijan for subsequent lending to the state oil and aluminum enterprises (IMF 2010b).

In fiscal policy, to signal to the population and enterprises its resolve to liberalize taxation, the government lowered profit and income tax rates, raised the VAT threshold to increase access to the simplified tax regime, and introduced 46 modifications to the tax code to increase taxpayer rights' protection and improve tax administration (Guliyeva 2009; IMF 2010a). Yet, it also maintained major tax exemptions and tolerated tax arrears, particularly from large public enterprises. ${ }^{5}$ Second, it made substantial transfers to the state budget from the state oil fund (SOFAZ) that held around \$11 billion in reserves in 2008 (SOFAZ 2010). While in 2007 nontax revenues made up around 13 percent of the budget revenues, in 2008 and 2009 these rose to about 37 and 50 percent, respectively, and came mostly from SOFAZ (Aslanli 2015; SOFAZ 2010). Third, while it cut non-priority spending and abstained from initiating new major capital investments in 2009, the government continued financing ongoing large-scale infrastructure projects of dubious quality, increased public sector wages in some areas, and doubled social spending from around 2 to 4 percent of GDP $^{6}$ (Aslanli 2015). Furthermore, it maintained the practice of extra-budgetary funds and quasi-fiscal activities, particularly through the state oil company (SOCAR) 7 , which provided considerable implicit subsidies to state-owned enterprises through low energy prices and toleration of payment arrears. ${ }^{8}$

After securing a second five-year term in October 2008 in elections characterized as neither free, nor fair, President Ilham Aliyev quickly moved to hold a nationwide referendum in March 2009 proposing a number of amendments to the constitution. The key one concerned the elimination of presidential term limits (RFE/RL 2008). This was likely done to preempt the grooming of potential challengers from within the elite, rather than official opposition, which was already weak ${ }^{9}$ (Freedom House 2010a; RFE/RL 2008). The timing indicates that the ruling elite, wary that the consequences of the global financial turmoil would exacerbate the thenlooming succession issue by undermining the president's patronage network, decided to preclude this before the effects of the crisis grow strong enough to fuel grievances and political realignments. To further boost the loyalty of supporters, the president also moved to re-appoint most top-level elite members to their positions and, most importantly, in effect removed term limits for several offices through constitutional amendments (AzeriReport 2009; Freedom House 2010a). Although the outcome of the referendum could not necessarily ensure a smooth term in office for Aliyev, such a solution to the succession issue raised the costs of intra-elite realignment and discouraged anti-elite mobilization by sending an unambiguous signal about continuity. ${ }^{10}$

Regarding repressive measures, on the one hand, the government continued repression of journalists, opposition figures, and student activists from OL! Movement (La Porte 2015), yet overall government repression levels showed a consistent decrease during the crisis, compared 
to previous years (Freedom House 2010a). In addition, while it sought to introduce further restraints on already marginalized foreign and local non-governmental organizations (NGOs) in 2009 by making several harsh legal amendments, subsequently it withdrew the bill (Trend News 2009). On the other hand, the ruling elite boosted its coercive capacity. Law enforcement spending grew from \$36 per capita in 2006 to $\$ 77$ and $\$ 91$ in 2008 and 2009, respectively. It increased spending for defense, justice, and law enforcement from 1.3 percent of GDP in 2008 to 1.8 of GDP in 2009, with a further 1.2 percent increase in 2010 (“Azerbaijan" Newspaper 2010).

\section{Kazakhstan}

Facing the first signs of the global turmoil and being more exposed to the crisis than its neighbors because of its deeper integration into the global financial system, the Nazarbayev administration responded with a package of policies that was "rapid, effective, and occasionally coercive" (Schatz and Maltseva 2012). First, it supported four largest banks - BTA, Halyk, Kazkommertsbank and Alyans - by providing the total of $\$ 4$ bn in return to 25-percent share in each bank. In early 2009, it injected another \$1 bn to Halyk and Kazkommertsbank, while practically nationalizing Alyans and BTA (Askarov 2010; EIU 2009). Second, it allowed a significant, 20 percent devaluation of the local currency (Tenge) (National Bank of Kazakhstan 2009). While this adversely affected the position of local businesses, it also tackled the economy's waning attractiveness for foreign investors (EIU 2010b).

In fiscal policy, the government increased pressure on international oil companies to increase its share of income through higher taxes in three largest ventures as well as ensure that local companies get larger shares in these consortia's supply and service contracts. It also started inquiries on tax evasion and violation of the labor code and environmental regulations ${ }^{11}$ (EIU 2009). These measures were probably taken for both extracting resources and appeasing the population. Apart from its own reserves, which stood at around $\$ 50$ billion (Schatz and Maltseva 2012: 50), the government secured two large loans for infrastructure projects from China and the World Bank (EIU 2009). In 2009, the natural resource fund (NRFK) made large transfers of around 7 percent of GDP to the unified state budget (Ministry of Finance 2010). Simultaneously, to placate popular tension and appease specific influential supporters, the government introduced a number of new taxes that targeted the wealthy (Schatz and Maltseva 2012), while also lowering some key taxes, most notably the corporate profit tax, ${ }^{12}$ and maintaining tax exemptions and tolerating arrears from specific companies. ${ }^{13}$

Although it cut budget spending by about 1 percent annually, the government also allocated considerable funds from the giant state holding company Samruk-Kazyna and NRFK to various industrial and infrastructure projects chosen through reportedly arbitrary process. ${ }^{14}$ The list of recipients is said to have included most of the enterprises under Samruk-Kazyna, "social corporations," and several other private companies reportedly linked to the ruling elite. ${ }^{15}$ The share of transfers to regions also increased to soothe regional tensions ${ }^{16}$ (Schatz and Maltseva 2012: 54). Despite the previous policy of reducing public sector employment - in 2007 the government initiated a 20 percent cut - in subsequent years of the crisis the number of employees in the public sector remained at previous levels. ${ }^{17}$

In terms of political measures, at the onset of the crisis in 2008 and in anticipation of looming intra-elite frictions fueled by impending political succession issue given the president's old age, President Nazarbayev initiated a government restructuring aimed at strengthening presidential control over various state bodies and the economy ${ }^{18}$ (Lillis 2009; Panchenko 2010). Two large state funds Samruk and Kazyna were merged into Samruk-Kazyna, which brought many state-owned or state-controlled enterprises under direct presidential control ${ }^{19}$ (SamrukKazyna 2010). Second, several ministries were reshuffled and reorganized (Silk Road Intelligencer 2010; EIU 2010b). A bill was passed that granted President Nazarbayev a "leader of the nation" status, which effectively meant he would be the country's de-facto leader after retirement (Lillis 2010). Finally, the government pro-actively used mass media to persuade the population not only that the crisis was caused externally and failed to destabilize the country's 
economy, but also that the administration used it skillfully to advance the country's interests (Schatz and Maltseva 2012).

The restructuring was accompanied by high-level reshuffles and persecution of several former high-level officials and several business leaders (Lillis 2009; RFE/RL 2009a, 2009b). Similar to Azerbaijan, overall repression levels somewhat decreased but simultaneously law enforcement spending increased from $\$ 89$ per capita in 2006 to $\$ 140$ and $\$ 133$ per capita in 2008 and 2009, respectively (State Statistics Committee 2009). Military expenditure grew from $\$ 60$ per capita in 2005 to $\$ 100$ in 2008 and 2010 (SIPRI 2010). When a rare anti-government protest erupted in 2011 in an oil town of Zhanaozen, it was swiftly crushed by government forces (Sindelar and Toiken 2012). To improve its image abroad, the ruling elite also secured consulting services of former UK Prime Minister Tony Blair for around $£ 5$ million annually. Blair helped justify the harsh measures taken in Zhanaozen, including the deaths of 14 protesters (Mendick 2014).

\section{Turkmenistan}

Turkmenistan's weak integration into global financial system, small foreign debt, and massive reserves relieved the government and the central bank from the need to make drastic adjustments in monetary and fiscal policies (EIU 2010c; RFE/RL 2009c). A major development was redenomination of local currency and unification of the official and the commercial exchange rates starting from 2009. Modest reforms were initiated in the financial sector, allowing banks to mobilize deposits and provide new services (EIU 2010c; IMF 2010d; RFE/RL 2009c).

The government made some cuts in public spending in 2009 and suspended some largescale construction projects, including upgrading of the main airport in Ashgabat (EIU 2010c; IMF 2010d; RFE/RL 2009c). However, it continued to finance several expensive construction projects. It provided considerable subsidies to state enterprises and households amounting to around a quarter of GDP, and tax exemptions to state enterprises ${ }^{20}$ (EIU 2010c). Furthermore, the authorities also increased the 2010 budget for public sector salaries and benefits by 11 percent (Turkmenistan.ru 2009). Overall, public sector employment remained one of the highest in the world with only 10 percent of labor force employed in the private sector (ILO 2010).

In terms of political measures, the administration of President Berdymukhamedov preserved all features of the hard-autocratic political system created by his predecessor Niyazov. The political power remained centralized in the presidency with one-party parliament serving as a rubber stamp for presidential initiatives. The president frequently reshuffled high-level officials to prevent them from forming power bases and to deflect the blame for policy failures away from himself. ${ }^{21}$ Although most of the fired officials were given posts in other government bodies, Berdymukhamedov also managed to distance most of the Niyazov protégés from top decision-making22 (Ozodi 2008; Pannier 2009; EIU 2010c).

In an attempt to attract foreign investment by creating a façade of political liberalization, in early 2010 Berdymukhamedov proposed to move away from one-party system and encouraged establishing an opposition party (TurkmenInform 2010). The global financial turmoil demonstrated the risks of dependence both on single commodity and on few routes for its transportation. Turkmenistan would not qualify for funding from such major donors as the European Bank for Reconstruction and Development (EBRD), whose financing of the TransCaspian gas pipeline to bring Turkmen gas to Europe bypassing Russia was conditional on Turkmenistan transforming into a multiparty system (Ferghana.ru 2010). The new party emerged in 2012 but, as expected, is tightly managed by the government (Lenta.ru 2013).

While Turkmenistan remained one of the most repressive states in the world (Freedom House 2010b), the overall repression levels during the crisis somewhat decreased while the size of armed forces in relation to the population and the spending on armed forced remained high (SIPRI 2010; World Bank 2016). The government also made generous arms purchases from abroad (Kommersant 2008). 


\section{ASSESSING DIFFERENT EXPLANATIONS}

\section{Savings Provided Safety Cushions}

A key similarity across the cases is the striking role played by considerable savings. These allowed the governments a sufficient room for manoeuvring and adjustment. Unlike many oilrich autocracies in 1970s, the new regimes adopted relatively more prudent fiscal policies during the pre-crisis boom. While prior to 1970 price shocks oil-rich government expenditure closely followed government revenue (Karl 1997), in 2ooos Azerbaijan and Kazakhstan recorded budget surpluses that were at least 5 times larger than those of their resource-poor neighbours. By 2007, Kazakhstan and Azerbaijan had accumulated foreign exchange reserves that were 5 and 2 times bigger in per capita terms, respectively, than Kyrgyzstan's reserves. ${ }^{23}$ When they faced the crisis, they had enough reserves to finance several years of low income.

When the windfalls sharply fell during the crisis, savings that were channelled into various extra-budgetary funds enabled sustaining expenditure. While the governments cut nonpriority spending and abstained from initiating new major capital investments, savings allowed a combination of policies of maintaining local currencies, tax exemptions, targeted capital investment, and increases in public sector wages and security spending. Naturally, different configurations of these policies reflected varying conditions.

In addition, a variety of extra-budgetary fund operations suggests that official statistics might not necessarily reflect actual amounts of spending and their destinations. In Turkmenistan extra-budgetary funds are estimated to be four times as large as the official state budget (EIU 2008). The 2010 state budget projected a cut of 15 percent in expenditure from the budget targets of 2009, but the government sponsored several infrastructure projects worth \$23.6bn (Eurasianet.org 2010). A seasoned Kazakh analyst described the official budget in Kazakhstan as a "Fil'kina gramota" - a Russian idiom for poorly written or legally void documents. ${ }^{24}$

\section{(Eclectic) Learning Helped Fine-Tune Policies}

Evidence also suggests that the governments in Kazakhstan and Azerbaijan benefited from some policy learning. In fiscal policy, the governments learned to balance distributional pressures with stabilization and saving concerns during boom years, which resulted in adopting natural resource funds ${ }^{25}$ (NRFs)(Ahmadov 2011; Guliyev 2013). However, the rulers' learning was likely to be subtler than the simpler motives of economic expediency and pacification of international donors, whose conditionality terms were hardly attractive to these governments given their wealth. For one, prior to the crisis the NRFs were not immune to raiding by the ruling elites, thus partly defying their economic purpose. Rather, drawing on the experience of Gulf states, the leaders in Central Asia realized that NRFs can serve a previously unobserved political purpose. By taking away the funds from the state budget, putting it under direct presidential control, and thus beyond the reach of other major actors, the NRFs provided an internationally legitimized means to institutionalize the autocrat's prerogative over the management of rents.

Furthermore, savings and subsequent expenditures came also from other extrabudgetary institutions. Here too one might discern the role of policy learning. The creation of a giant government holding Samruk-Kazyna in Kazakhstan, widely credited with its stabilizing role in 2008-2009, resulted from learning from Malaysia's and Singapore's experience in tackling the Asian financial crisis in $1997^{26}$ (Khamidov 2014). Equipped with the benefit of hindsight, during the crisis the governments also avoided the temptation to curtail spending largely due to concerns of sustaining aggregate demand as well as maintaining patronage networks.

Azerbaijan's lower exposure to the crisis than Kazakhstan's may also be due to lessondrawing. Following the lessons of the 1997 Asian financial crisis President Heydar Aliyev was wary of economic and political consequences of allowing foreign capital in the financial sector. ${ }^{27}$ Therefore, after initial experimenting with privatization, ultimately only one of the four largest 
banks was privatized and the country's financial sector remained largely under government control (Masimov 1999).

Key sources of fiscal policy learning were the experience of their reference groups, particularly neighbors and similar states elsewhere as well their own prior experience in 1990s. The rulers drew on the experience of Gulf monarchies in 1970s-1980s, Kazakhstan and Azerbaijan established oil funds soon after the 1997 Asian financial crisis, and Samruk-Kazyna in Kazakhstan was modeled after Malaysia's sovereign wealth fund Khazanah Nasional Berhad ${ }^{28}$ (IMF 2009). A large resource exporter, Malaysia fared better than its neighbors during the Asian financial crisis, and Kazakh government had established close cooperation with Malaysia's state financial institutions to draw on their policy solutions. ${ }^{29}$

Although policy learning was pronounced in fiscal policy, it was not limited to this area. On political measures ruling elites borrowed policies aimed at safeguarding their continuity in office and smooth political succession to a trusted heir in the face of the global turmoil. In Azerbaijan, Aliyev's elimination of presidential term limits drew from the experience of Kazakhstan, where this policy had been successfully probed. The ruling elites in Azerbaijan also seemed to seriously consider resolving the succession issue by following Russia's "tandem" example: as Putin passed power to a trusted protégé Medvedev in May 2008, Ilham Aliyev would pass the bridles to his wife Mehriban Aliyeva. ${ }^{30}$ The ruling elites also learned pre-emptive manipulation, choosing more selective targeting strategies, and drawing on foreign advice to represent repressive measures in a different light, such as soliciting consultancy services of Tony Blair. In monetary policy, Kazakhstan's experience provided a lesson to the ruling elite in Azerbaijan who utilized it both to prepare for the second phase of the crisis and justify the slow pace of financial sector reforms. ${ }^{31}$

\section{Steadfast Coercive Capacity}

Evidence also demonstrates the difference between repression and coercive capacity. Across three cases, repression levels decreased. Figure 2 shows improvement in physical integrity rights index in the oil-rich autocracies after 2007. However, Figure 3 suggests that coercive capacity either increases before and during the crisis or remains constantly higher than in resource-poor neighbours. Allocations to maintain or boost coercive capacity were made possible by selective allotments. Consequently, the fiscal health of the security establishments was not compromised. ${ }^{22}$ Table 1 provides a detailed analysis.

[Figure 2 here]

[Figure 3 here]

It shows that prior to the crisis, Azerbaijan, Kazakhstan, and Turkmenistan allocated significantly more resources to their coercive capacity than Kyrgyzstan and Tajikistan. Such coercive capacity considerably deterred dissent and anti-elite mobilization, ${ }^{33}$ while the political regime of Kurmanbek Bakiyev in Kyrgyzstan fell in 2010 as a result of popular protest. ${ }^{34}$

[Table 1 here]

In addition, in the decade prior to the crisis, government crackdown substantially weakened the political, economic, and physical infrastructure for political opposition in Azerbaijan and Kazakhstan. This included their pre-electoral intimidation, repression of their media outlets and associated business ventures, strict laws on the freedom of assembly, eviction from offices, and overt repression of individual activists ${ }^{35}$ (Ahmadov 2011; Guliyev 2013; La Porte 2015; Schatz and Maltseva 2012). Subsequently, prior to the crisis opposition forces were weakened, although not eliminated from the political scene as in Turkmenistan. This supports the hypothesis on the path-dependent effects of prior repression.

Finally, prior to pre-crisis boom years, in all three countries the security establishments, including the police and the army, remained or came to be part of a complex amalgam of patrimonial and kinship networks (Ahmadov 2011; Guliyev 2012; Overland, Kjaernet, and Kendal-Taylor 2010; Satpaev 2007). Although prior purges included specific individuals from security forces, by the beginning of the crisis these networks were significantly consolidated. In 
contrast, the downfall of President Bakiyev in Kyrgyzstan, for example, owed largely to the fact that, unlike the police, the army retained its autonomy during his rule and did not intervene to support him (Marat 2010).

\section{International Support and Timing of Late Development}

The role of international support is less clear-cut. On the one hand, in the case of Kazakhstan, the country received two large loans for infrastructure projects, although whether these made major difference is hard to argue because the government already had substantial savings. In addition, Western countries exerted little criticism or political pressure on the ruling elites, and Chinese investment was accompanied by its indifference to how the countries are run politically (Overland, Kjaernet, and Kendal-Taylor 2010).

On the other hand, there is little evidence to suggest that foreign governments or corporations were approached or lent resources to specifically support political regimes. On the contrary, Kazakh government used the crisis as an opportunity to pressure Western oil companies into making concessions, thus exacerbating its relations with respective foreign governments. Russia shut down gas exports from Turkmenistan. Second, all three governments still pursued multi-vector foreign policies. Third, even Russia, which was assertive in its "near abroad" policies, was not consistent in supporting autocrats but rather those political forces, incumbent or opposition, that sided with Russian interests (Way 2015). This is not to deny that, should the crises have deepened, we could have witnessed foreign support. Nonetheless, the governments were able to fend off the challenges using their own resources. It is possible that some oil-rich autocracies have learned to be autonomous and do without external help.

Finally, following the logic of the argument on the timing of late development, we would expect that since Turkmenistan had weak societal opposition and access to large rents in the beginning of its independence, it would have a shallow rent-based coalition that was more likely to experience regime instability during the 2008 crisis than Azerbaijan and Kazakhstan. However, there is no indication that these differences mattered. In addition, contrary to this theory's assumptions, the size of the ruling coalitions changed considerably. While initially Azerbaijan and Kazakhstan sustained broader coalitions in 1990s than Turkmenistan, over time these were significantly trimmed (Ahmadov 2011). Having consolidated their power, leaders followed an incentive to sustain what looked like a minimal-size winning coalition (Riker 1962). These findings do not invalidate the argument on the timing of late development but suggest that it has limited explanatory power in these cases.

\section{CONCLUSIONS AND IMPLICATIONS}

Despite the conventional view that oil-rich autocracies are susceptible to instability or even breakdown during external economic crises, such regimes in Central Eurasia remained firmly stable in the face of what many consider the most dramatic financial shock since the 1930 os Great Depression. The evidence here shows that scholars and international development community need to take into account three interrelated critical factors that bolstered autocratic stability. First, contrary to influential arguments, such as by Beblawi and Luciani (1987) and Karl (1997), who thought that overspending during booms leaves oil-rich governments with few means to survive during busts, prior to the crisis the regimes amassed sizeable savings that later provided safety cushions.

Second, the ruling elites' responses to the crisis highlighted their ability to update their know-how through drawing lessons from their own past experience and that of their reference groups. In addition, far from being naïve consumers of advice of international development organizations and adopting simply fashionable or economically prudent institutions, the autocratic rulers learned to instrumentalize such tools as stabilization funds to serve subtler political objectives. Furthermore, policy learning went beyond fiscal policy to include lessons from successful political measures and coercion policies elsewhere. Contrary to Orihuela's 
(2013) argument, these findings show how ruling elites learn to not escape the resource curse, but to escape despite the resource curse. Of course, the role of lesson-drawing should not be overstated. For example, in Azerbaijan sizeable savings accumulated even despite less cautious fiscal policy, i.e. potential lack of learning, than in Kazakhstan and Russia. But it should caution us not to underestimate oil-rich rulers' capacity for learning and to anticipate unintended consequences of well-meaning foreign advice.

Finally, the case study evidence suggests a continuing importance of coercion (Bellin 2004; Skocpol 1982; Wright et al. 2013) while showing the importance of distinguishing repression from coercive capacity. Future investigation with a larger number of cases is needed to examine the external validity of these arguments. One such case would be the stability of Putin regime in Russia, which shares some features with its post-Soviet counterparts studied in this article. Given how it weathered the global financial crisis, has remained stable in the face of subsequent Western sanctions, and seems to have skilfully combined its resources, the three factors proposed in this study may help cast light on its robustness.

These findings also call attention to two major issues in the study of the effects of economic crises on political regimes. The first is the question of temporality and its considerable effect on units of analysis (see Grzymala-Busse 2011). Many cross-national large-N studies treat political regimes across time as entities that have the same modus operandi. However, this article joins other studies of authoritarian adaptation in showing that the passage of time has a considerable effect on the maturity of these regimes and involves path-dependencies. Second, the findings suggest that to understand autocratic stability amid economic crises we need to recognize and factor in the diversity of even the crises and regimes that initially look similar. For instance, milder economic crises may teach autocracies without shaking their stability, so when a major shock hits, they are well prepared. Furthermore, even similar crises can affect similar countries differently due to specific configurations of structures and institutions within each. In line with several previous accounts on the role of domestic context (Ambrosio 2017; Lowi 2004; Moore 2002; Pepinsky 2009), the evidence here suggests that while economic crises may contribute to the forces of regime instability in oil-rich autocracies, ultimate outcomes will depend on these configurations of factors. A nuanced attention to such constellations is critical for both rigorous scholarship and sound policies regarding oil-rich autocracies.

\section{ENDNOTES}

${ }^{1}$ Following the convention, I use "oil" and "petroleum" to refer to "oil and gas resources".

${ }^{2}$ For reviews, see Ahmadov and Guliyev (2016) and Ross (2012).

3 Respondents were identified through a combination of purposive and snowball sampling. Observations from interviews were triangulated using other interviews and other types of evidence. Interviews took place in Baku (Azerbaijan), Almaty/Astana (Kazakhstan), and Ashgabat (Turkmenistan).

${ }^{4}$ Interview with local NGO director 1 (respondent 3463), May 2010, Baku.

${ }^{5}$ Interview with Ministry of Taxes official (respondent 1648), May 2009, and local economist 1 (respondent 4365), June 2009, Baku.

${ }^{6}$ Interview with local think tank director 1 (respondent 4161), June 2009, Baku.

7 Interview with Ministry of Economic Development official (respondent 8171), May 2009, Baku.

${ }^{8}$ Interviews with local economist 2 (respondent 2870 ) and member of parliament (independent) (respondent 6278), June 2009, and local NGO director 2 (respondent 6563), May 2010, Baku.

${ }^{9}$ Interview with member of parliament (independent) (respondent 6278), June 2009, Baku.

${ }^{10}$ Interviews with high-ranking member of ruling party (respondent 5247) and member of parliament (independent) (respondent 6278), June 2009, Baku.

${ }^{11}$ Interview with local journalist (respondent 2426), September 2009, Almaty. 
${ }^{12}$ Interview with Ministry of Education and Science official (respondent 1459), September 2009, Astana.

${ }^{13}$ Interview with international auditor 1 (respondent 6646) and international auditor 2 (respondent 9404), September 2009, Almaty.

${ }^{14}$ Interview with local think tank director 3 (respondent 6807), October 2009, Almaty.

${ }^{15}$ Interviews with local think tank director 2 (respondent 3557), country director of international NGO (respondent 2225) and local auditor 1 (respondent 8108), October 2009, Almaty.

${ }^{16}$ Interview with former minister (respondent 8406), October 2009, Almaty.

${ }^{17}$ Interview with international NGO analyst (respondent 4511), October 2009, Almaty.

${ }^{18}$ Interviews with local think tank director 1 (respondent 7517), October 2009, and with local auditor 2 (respondent 6820), November 2009, Almaty.

${ }^{19}$ Interview with local think tank director 2 (respondent 3557), September 2009, Almaty, and Ministry of Economic Development and Trade official (respondent 3637), September 2009, Astana.

${ }^{20}$ Interview with international inter-governmental organization executive (respondent 1921), March 2010, Ashgabat.

${ }^{21}$ Interview with former government official (respondent 7347), March 2010, Ashgabat.

${ }^{22}$ Interview with local NGO director (respondent 7969), March 2010, Ashgabat.

${ }^{23}$ Author's calculations based on data from WDI and national statistical offices.

${ }^{24}$ Interview with local journalist (respondent 2426), September 2009, Almaty; a similar note was made by a local economist and politician (respondent 3277), May 2009, Baku.

${ }^{25}$ Interview with high-ranking government official in energy sector (respondent 8950), May 2009, Baku ,and with National Bank official (respondent 9103), September 2009, Almaty.

${ }^{26}$ Interviews with former minister (respondent 8406) and high-ranking "Samruk-Kazyna" official (respondent 8505), September/October 2009, Astana.

${ }^{27}$ Interview with former advisor to President Heydar Aliyev (respondent 706o) and high-level Chamber of Accounts official (respondent 1686), July 2009, Baku; this could also explain slow privatization, according to former major state enterprise director (respondent 6564), interview, June 2010, Baku.

${ }^{28}$ Interview with high-ranking "Samruk-Kazyna" official (respondent 8505), September 2009, Astana.

${ }^{29}$ Interview with high-ranking "Samruk-Kazyna" official (respondent 8505) and Ministry of Economic Development and Trade official (respondent 3637), September 2009, Astana.

$3^{30}$ Interview with high-ranking member of ruling party (respondent 5247), June 2009, Baku.

${ }^{31}$ Interview with National Bank official (respondent 2223), May 2009, Baku.

${ }^{32}$ Interview with former member of parliament (respondent 9833), May 2009, Baku, and Ministry of Economic Development and Trade official (respondent 3637), September 2009, Astana.

33 Interview with opposition party leader 1 (respondent 5240) and member of parliament (independent) (respondent 6278), June 2009, Baku; and former minister (respondent 8406) and local political analyst 2 (respondent 9898), October 2009, Almaty.

${ }^{34}$ Although Azerbaijan's military expenditure partly reflects its involvement in a frozen conflict with Armenia, it includes spending on paramilitary groups that have been used for clamping down domestic dissent (RFE/RL 2003, 2005).

35 Interview with opposition party leader 1 (respondent 5240) and opposition party leader 2 (respondent 6908), June 2009, Baku; with country director of international NGO (respondent 1289) and local think tank director 2 (respondent 1215), October 2009, Almaty. 


\section{REFERENCES}

Ahmadov, Anar K. 2011. "A Conditional Theory of the 'Political Resource Curse'." PhD Thesis, LSE.

Ahmadov, Anar K. 2014. Blocking the pathway out of the resource curse: What hinders diversification in resource-rich developing countries?. No. 2014/98. GEG Working Paper.

Ahmadov, Anar K., and Farid Guliyev. 2016. "Tackling the Resource Curse: The Role of Democracy in Achieving Sustainable Development in Resource-Rich Countries." IDEA Discussion Paper.

Anderson, Lisa. 1987. "The State in the Middle East and North Africa." Comparative Politics 20(1):1-18.

——_. 2011. "Demystifying the Arab Spring." Foreign Affairs, 3.

Askarov, Tulegen. 2010.“'Krysha' Dlya BTA i 'Alyansa' (A 'Cover' for BTA and Alyans).” Golos Respubliki, February 26.

Aslanli, Kenan. 2015. “Fiscal Sustainability and the State Oil Fund in Azerbaijan.” Journal of Eurasian Studies 6(2):114-21.

“Azerbaijan” Newspaper.2010.“Illik Milli Budcə (Annual State Budget).” Azerbaijan Newspaper, June 20 .

AzeriReport. 2009. “Azerbaijan Will Vote On Constitutional Changes On March 18.” 2009. http://azerireport.com/index.php?option=com_content\&task=view\&id=1106\&Itemid=4 2.

Beblawi, Hazem, and Giacomo Luciani. 1987. The Rentier State. Croom Helm.

Beissinger, Mark. 2007."Structure and Example in Modular Political Phenomena.” Perspectives on Politics 5(02):259-76.

Bellin, Eva. 2004.“The Robustness of Authoritarianism in the Middle East.” Comparative Politics 36(2):139-57. 
Brownlee, Jason. 2002.“...And yet They Persist: Explaining Survival and Transition in Neopatrimonial Regimes.” Studies in Comparative International Development 37(3):3563.

———. 2017."The Limited Reach of Authoritarian Powers." Democratization 24(7):1326-44.

Cameron, David, and Mitchell Orenstein.2012."Post-Soviet Authoritarianism: The Influence of Russia in Its 'Near Abroad.” Post-Soviet Affairs 28(1):1-44.

Chestnut, Sheena. 2010. "Regime Security and Counter-Diffusion." Democracy E Society 7(2):58.

Cingranelli, David L., David L. Richards, and K. Chad Clay. 2014."The CIRI Human Rights Dataset."

Dolowitz, David, and David Marsh. 20oo. "Learning from Abroad: The Role of Policy Transfer in Contemporary Policy-making." Governance 13(1):5-23.

Dunning, Thad. 2005. "Resource Dependence, Economic Performance, and Political Stability." Journal of Conflict Resolution 49(4):451-82.

EIU. 2008. “Country Profile: Turkmenistan.” London: Economist Intelligence Unit.

—__. 2009. “Country Report: Kazakhstan.” London: Economist Intelligence Unit.

—__. 2010a. “Country Report: Azerbaijan.” London: Economist Intelligence Unit.

——_. 201ob. “Country Report: Kazakhstan.” London: Economist Intelligence Unit.

——_. 2010c. “Country Report: Turkmenistan.” London: Economist Intelligence Unit.

Elkins, Zachary, and Beth Simmons. 2005. "On Waves, Clusters, and Diffusion.” Annals of the American Academy of Political and Social Science 598:33-51.

Eurasianet.org. 2010. "Berdymukhamedov Plans Massive Infrastructure Investment." http://www.eurasianet.org/departments/news/articles/eavo12o1od.shtml.

Ferghana.ru. 2010. "Prezident Zakhotel Novuyu Partiyu (President Wants a New Party)," May 14. http://www.fergananews.com/news.php?id=14729. 
Freedom House. 2010a."Azerbaijan.” In Nations in Transit 2010. Washingdon, DC: Freedom House.

——_. 201ob.“Turkmenistan.” In Nations in Transit. New York: Freedom House.

Friedman, Thomas. 2006. “The First Law of Petropolitics.” Foreign Policy.

Gasiorowski, Mark J. 1995.“Economic Crisis and Political Regime Change.” American Political Science Review 89(04):882-97.

Gel'man, Vladimir, and Tomila Lankina.20o8.“Authoritarian Versus Democratic Diffusions: Explaining Institutional Choices in Russia's Local Government.” Post-Soviet Affairs $24(1): 40-62$.

Grzymala-Busse, Anna. 2011. "Time Will Tell? Temporality and the Analysis of Causal Mechanisms and Processes." Comparative Political Studies 44(9):1267-97.

Guliyev, Farid. 2012. "Political Elites in Azerbaijan." In Andreas Heinrich and Heiko Pleines, Eds., Challenges of the Caspian Resource Boom, 117-30. Houndmills:Palgrave.

———. 2013. “Oil and Regime Stability in Azerbaijan.” Demokratizatsiya 21(1):113-47.

Guliyeva, Nurlana. 2009. “Nalogi Snizhayutsya, Kontrol' Rastet (Taxes Are Reduced, Control Heightened)." RegionPlus, January 7. http://regionplus.az/az/articles/view/4051.

Haggard, Stephan, and Robert Kaufman. 1995. The Political Economy of Democratic Transitions. Princeton University Press.

Hall, Peter. 1993. "Policy Paradigms, Social Learning, and the State." Comparative Politics, 27596.

Hall, Stephen, and Thomas Ambrosio. 2017."Authoritarian Learning: A Conceptual Overview.” East European Politics 33(2):143-61.

Heydemann, Steven, and Reinoud Leenders. 2011.“Authoritarian Learning and Authoritarian Resilience.”' Globalizations 8(5):647-53.

Ibadoglu, Qubad. 2010. “Azərbaycan Iqtisadiyyatı 2009 (Azerbaijan’s Economy 2009).” Baki: İqtisadi Tədqiqatlar Mərkəzi. 
ILO. 2010. “LABORSTA Labour Statistics Database.” International Labour Organization.

IMF. 2009.“Turkmenistan: Article IV Consultation.” Washington, DC: International Monetary Fund.

——_. 2010a."Azerbaijan: Article IV Consultation.” Washington, DC: International Monetary Fund.

—__. 2010b.“Azerbaijan: Selected Issues.” Washington, DC: International Monetary Fund.

——_. 2010c.“Kazakhstan: Selected Issues.” Washington, DC: International Monetary Fund.

—_- 2010d."Turkmenistan: Selected Issues.” Washington, DC: International Monetary Fund.

_—_. 2011.“Government Finance Statistics.” International Monetary Fund.

Karl, Terry Lynn. 1997. The Paradox of Plenty. Berkeley: University of California Press.

_—_. 1999. “The Perils of the Petro-State." Journal of International Affairs 53(1):31-52.

Khamidov, Alisher. 2014. "Kazakhstan Grapples With Reform of Sovereign-Wealth Fund." Eurasianet.Org, August 4. https://eurasianet.org/s/kazakhstan-grapples-with-reformof-sovereign-wealth-fund.

Kommersant. 2008."Turkmenistan Buys Russian Weapons.” http://www.kommersant.com/page.asp?id=905617.

Kurzman, Charles. 1996. "Structural Opportunity and Perceived Opportunity in SocialMovement Theory: The Iranian Revolution of 1979." American Sociological Review 61 (1): $153-70$.

La Porte, Jody. 2015. "Hidden in Plain Sight: Political Opposition and Hegemonic Authoritarianism in Azerbaijan." Post-Soviet Affairs 31(4):339-66.

Lenta.ru. 2013. "Parlament Turkmenii Stal Dvukhpartiynym (The Turkmen Parliament TwoParty).” June 11.

Lillis, Joanna. 2009. “Corruption Scandals an Indicator of Clan Infighting in Astana?” November 5. http://www.eurasianet.org/departments/insightb/articles/eavo710oga.shtml.

——_. 2010. "A Modest 'Leader of the Nation.” 2010. http://www.eurasianet.org/node/61312. 
Linz, Juan, and Alfred Stepan. 2011. Problems of Democratic Transition and Consolidation. Johns Hopkins University Press.

Lowi, Miriam R. 2004.“Oil Rents and Political Breakdown in Patrimonial States.” The Journal of North African Studies 9(3):83-102.

Luciani, Giacomo. 1994. "The Oil Rent, the Fiscal Crisis of the State and Democratization.” In Democracy Without Democrats?, edited by Ghassan Salamé. New York: Tauris.

Luong, Pauline Jones, and Erika Weinthal. 2010. Oil Is Not a Curse. Cambridge University Press. Marat, Erica. 2010. "Bakiyev, the Security Structures, and the April 7 Violence in Kyrgyzstan." Central Asia-Caucasus Analyst, April 29.

Masimov, Ali. 1999. "Privatizatsiya v Azerbaijane (Privatization in Azerbaijan).” Tsentral'naya Aziya i Kavkaz 4.

Mendick, Robert. 2014. “Tony Blair Gives Kazakhstan’s Autocratic President Tips on How to Defend a Massacre." Telegraph, August 24.

Milli Bank. 2009. “illlik Hesabat (Annual Report).” Baki: Azerbaycan Milli Banki (National Bank of Azerbaijan).

Ministry of Finance. 2010. “2009 Report.” Astana, Kazakhstan: Ministry of Finance.

Moore, Pete. 2002. "Rentier Fiscal Crisis and Regime Stability." Studies in Comparative International Development 37(1):34-56.

National Bank of Kazakhstan. 2009."Annual Report.” Astana, Kazakhstan: National Bank of Kazakhstan.

Orihuela, José Carlos. 2013. “How Do ‘Mineral-States’ Learn?” World Development 43:138-48.

Overland, Indra, Heidi Kjaernet, and Anrea Kendal-Taylor, eds. 2010. Caspian Energy Politics. London: Routledge.

Ozodi, Devlet. 2008. “Ashkhabad: Retsepty i Proyekty (Ashkhabad: Prescriptions and Projects).” 2008. http://www.gundogar.org/?01800ooooooooooooo1100oooo. 
Panchenko, Tatyana. 2010. "Yedinoy Tsepyu Vsyu Stranoy (One Chain for the Whole Country)." Golos Respubliki, July 9.

Pannier, Bruce. 2009. “Turkmenistan's 'Gray Cardinal' Leaves Government.” 2009. http://www.gundogar.org/?0220047285000000000000011000000.

Pepinsky, Thomas. 2009.Economic Crises and the Breakdown of Authoritarian Regimes. Cambridge University Press.

RFE/RL. 2008."Azerbaijani Parliament Proposes Scrapping Presidential Term Limits.” RFE/RL, 2008.

https://www.rferl.org/a/Azerbaijani_Parliament_Proposes_Scrapping_Presidential_Ter m_Limits/1361668.html.

———. 2009a. "Former Kazakh Environment Minister Arrested For Embezzlement." http://www.rferl.org/content/former_kazakh_environment_minister_arrested_for_em bezzlement/1564630.html.

-_- 2009b. "Kazakh Uranium Magnate Charged With Corruption." http://www.rferl.org/content/Kazakh_Uranium_Magnate_Charged_With_Corruption/ 1900718.html.

- - 2009c. "Turkmenistan Redenominates Currency."

http://www.gundogar.org/?0220047174000000000000011000000.

Riker, William H. 1962. The Theory of Political Coalitions. Yale University Press.

Ross, Michael. 2001. “Does Oil Hinder Democracy?” World Politics 53(3):325-61.

——_. 2012. The Oil Curse. Princeton, NJ: Princeton University Press.

Ross, Michael, and Paasha Mahdavi. 2015."Oil and Gas Data, 1932-2014." https://doi.org/10.7910/DVN/ZTPWoY.

Satpaev, Dosym. 2007.“An Analysis of the Internal Structure of Kazakhstan's Political Elite.” In U. Tomohiko (ed.) Empire, Islam and Politics in Central Asia. Sapporo: Slavic Eurasian Research Center. 
Schatz, Edward. 2009.“The Soft Authoritarian Tool Kit.” Comparative Politics 41(2):203-22.

Schatz, Edward, and Elena Maltseva. 2012. “Kazakhstan's Authoritarian 'Persuasion.”' PostSoviet Affairs 28(1):45-65.

Schmotz, Alexander, and Oisín Tansey. 2018. "Regional Autocratic Linkage and Regime Survival." European Journal of Political Research 57(3):662-86.

Silk Road Intelligencer. 2010. "Kazakhstan Creates New Oil and Gas Ministry in a Major Government Reshuffle.” 2010. http://silkroadintelligencer.com/2010/03/15/kazakhstancreates-new-oil-and-gas-ministry-in-a-major-government-reshuffle/.

Sindelar, Daisy, and Sania Toiken. 2012. "A Year After Deadly Riots, Zhanaozen Is Quiet But Angry.” RFE/RL, December 16, 2012. https://www.rferl.org/a/zhanaozen-a-year-afterthe-riots/24798726.html.

SIPRI. 2010. “Military Expenditure Database.” Stockholm International Peace Research Institute.

Skocpol, Theda. 1982. "Rentier State and Shi'a Islam in the Iranian Revolution." Theory and Society $11(3): 265-83$.

Smith, Benjamin. 2004."Oil Wealth and Regime Survival in the Developing World, 1960-1999." American Journal of Political Science 48(2):232-46.

———. 2006. "The Wrong Kind of Crisis: Why Oil Booms and Busts Rarely Lead to Authoritarian Breakdown." Studies in Comparative International Development 40(4):5576.

———. 2007. Hard Times in the Land of Plenty. Ithaca: Cornell University Press.

Snyder, Richard. 1998. "Paths out of Sultanistic Regimes.” In Sultanistic Regimes, H.E.Chehabi and Juan J. Linz (eds.). Baltimore: Johns Hopkins University Press.

SOFAZ. 2010.“Annual Report.” Baku: State Oil Fund.

State Statistics Committee. 2009.“Oficial'naya Statisticheskaya Informaciya (Official Statistical Information).” Astana: Kazakhstan State Statistics Committee.

Stempel, Jonathan. 2010.“Kazakh Lender BTA Bank Files U.S. Bankruptcy.” Reuters, February 5. 
SWFI. 2017."Sovereign Wealth Fund Rankings." Seattle, WA: Sovereign Wealth Fund Institute. Tansey, Oisín. 2016. “The Problem with Autocracy Promotion.” Democratization 23(1):141-63. Trend News. 2009. “ATəT Sədri Azərbaycanda QHT Haqqında Qanuna Edilən Son Dəyişiklikləri Bəyənir (OSCE Chairman Commends Latest Changes to NGO Law)." http://az.trend.az/news/politics/foreign/1497688.html.

TurkmenInform. 2010. "V Turkmenistane Doljna Poyavitsya Novaya Partiya (A New Party Should Appear in Turkmenistan)." http://www.turkmeninform.com/ru/news/20100219/o2288.html.

Turkmenistan.ru. 2009. "V Turkmenistane Rassmotren Proyekt Gosudarstvennogo Byudjeta (The Draft State Budget Was Considered in Turkmenistan)." http://www.gundogar.org/?topic_id=25;year=2009;month=11\#8702.

Vanderhill, Rachel. 2012. Promoting Authoritarianism Abroad. Boulder, Colo: Lynne Rienner Publishers.

Way, Lucan A. 2015. "The Limits of Autocracy Promotion."' European Journal of Political Research 54(4):691-706.

Weyland, Kurt. 2017. “Autocratic Diffusion and Cooperation.” Democratization 24(7):1235-52. World Bank. 2016. "World Development Indicators.” World Bank.

Wright, Joseph, Erica Frantz, and Barbara Geddes. 2013.“Oil and Autocratic Regime Survival.” British Journal of Political Science 45:287-306.

Yom, Sean L, and F Gregory Gause. 2012."Resilient Royals: How Arab Monarchies Hang On.” Journal of Democracy 23(4):74-88. 


\section{TABLES}

Table 1 Pre-Crisis Coercive Capacity, Average 2005-2007

\begin{tabular}{lcccc}
\hline Country & $\begin{array}{c}\text { Armed forces } \\
\text { personnel (\% of } \\
\text { total labor force) }\end{array}$ & $\begin{array}{c}\text { Armed forces } \\
\text { personnel per } \\
\text { 10oo inhabitants }\end{array}$ & $\begin{array}{c}\text { Law } \\
\text { enforcement } \\
\text { spending per } \\
\text { capita (in } \\
\text { constant USD) }\end{array}$ & $\begin{array}{c}\text { Military } \\
\text { expenditure per } \\
\text { capita (in } \\
\text { constant USD) }\end{array}$ \\
\hline Azerbaijan & 2.0 & 9.7 & 36.2 & 140.9 \\
\hline Kazakhstan & 1.1 & 5.7 & 89.0 & 78.1 \\
\hline Turkmenistan & 1.2 & 4.9 & na & 87.7 \\
\hline Kyrgyz Republic & 0.8 & 3.8 & 8.4 & 28.0 \\
\hline Tajikistan & 0.5 & 2.3 & na & 26.7
\end{tabular}

Source: Author's calculations based on data from national statistical agencies, World Bank (2016) and SIPRI (2010). 


\section{FIGURES}

Figure 1. Changes in GDP growth

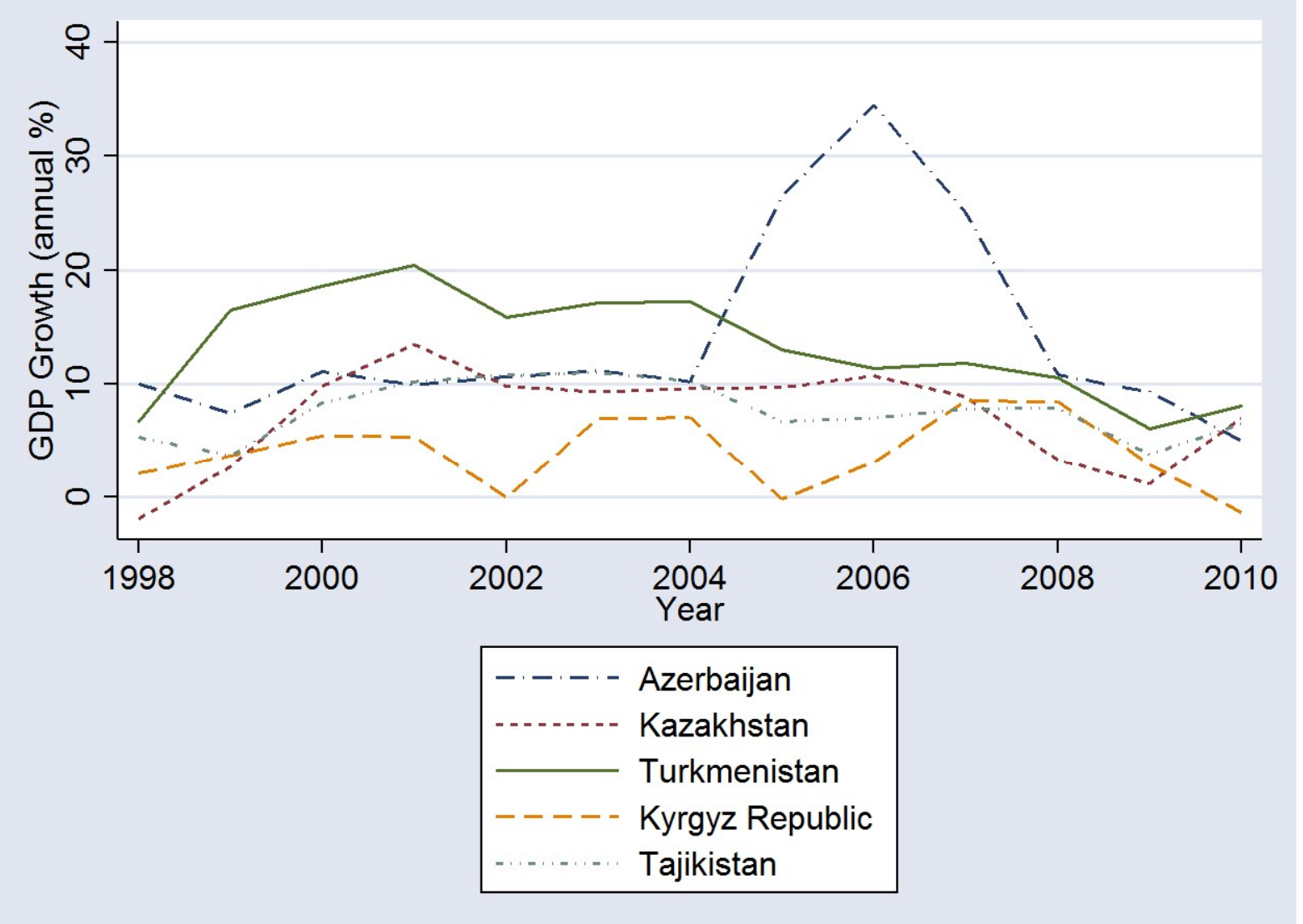


Figure 2. Repression

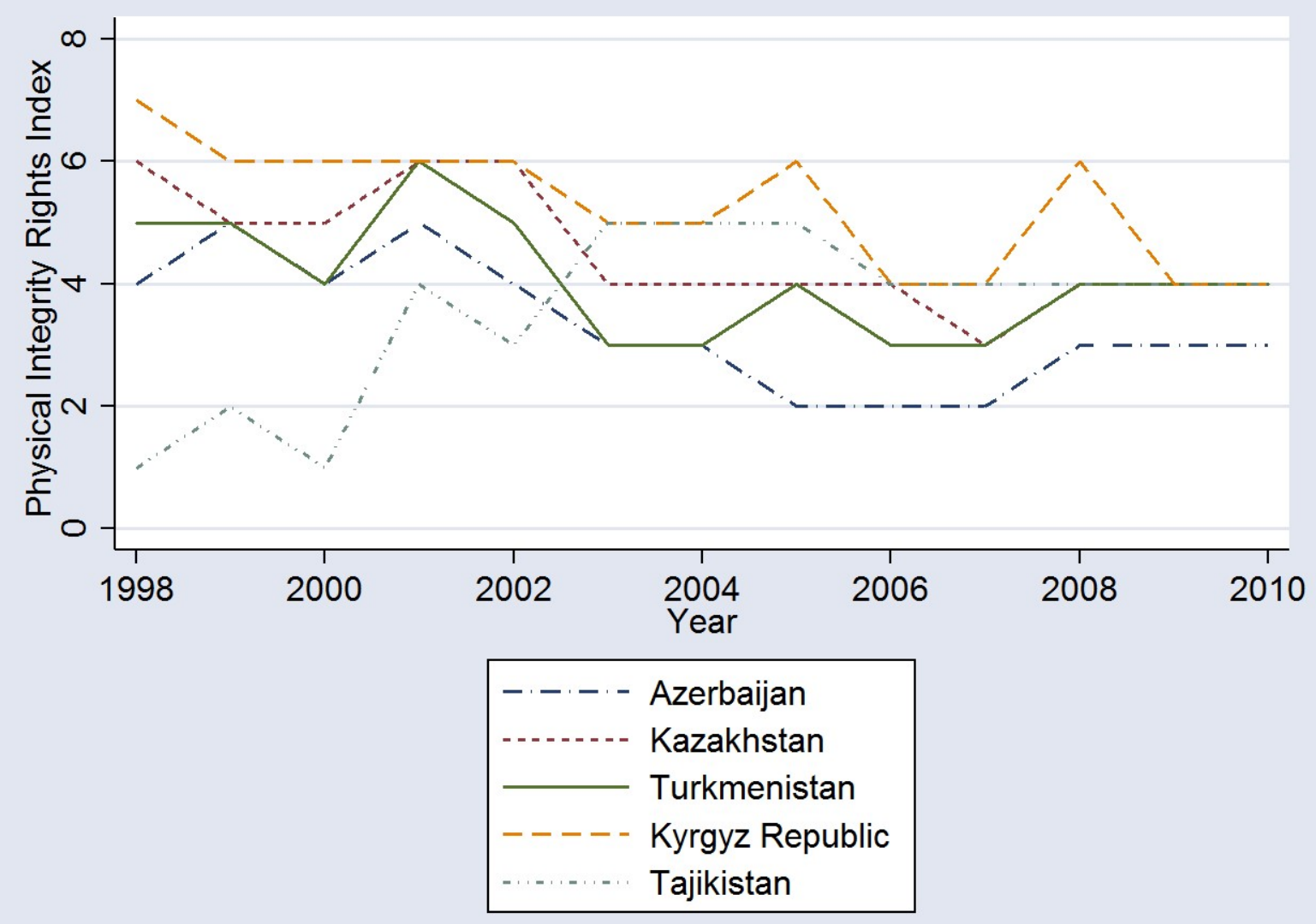


Figure 3. Coercive Capacity

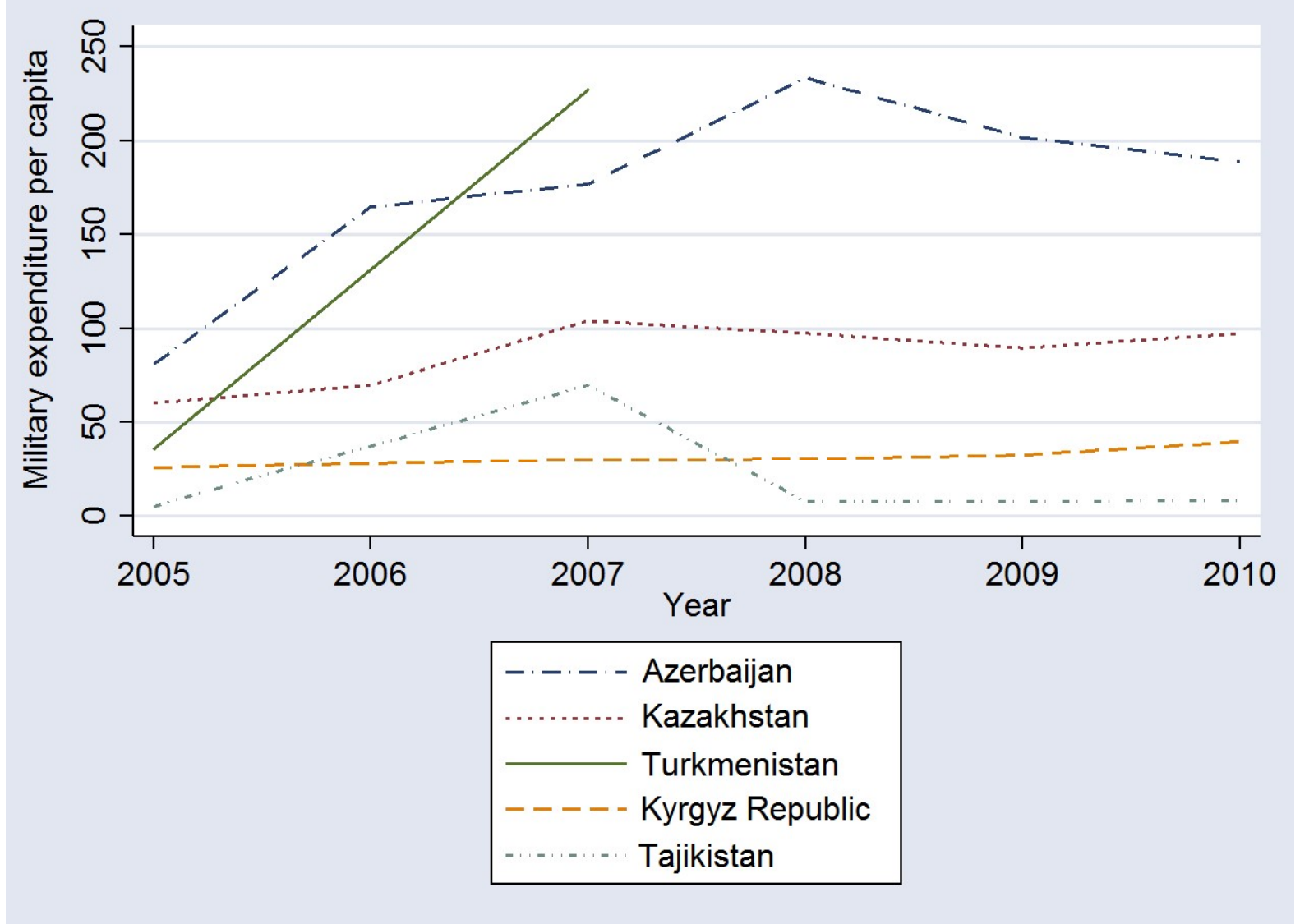

